doi: $10.15407 /$ ujpe61.09.0800

I.P. ILCHISHIN, T.V. MYKYTIUK

Institute of Physics, Nat. Acad. of Sci. of Ukraine

(46, Nauky Ave., Kyiv 03680, Ukraine)

PACS 42.55.TV

\title{
PHOTOTUNING OF THE FREQUENCY OF A CLC-LASER AND WAYS OF ITS OPTIMIZATION ${ }^{1}$
}

\section{Introduction}

The use of cholesteric liquid crystals, which have a natural periodic structure in lasers, allowed one to create laser cavity mirrors [1] and a laser with distributed feedback (DFB) or CLC-laser [2] on their basis. The study of these lasers is developing quite actively at the present time due to their promising practical application to the design of high-brightness laser displays, capable to work under the conditions of intense sunlight. The angular divergence of a CLClaser reaches tens of angular degrees because of the small thickness of the active layer equal to tens of microns and is characterized by rings in the spatial pattern of radiation [3]. Rings arise due to the scattering of the radiation of longitudinal modes in the CLC and the interference generated in the scattering of sloping beams. The investigation of the energetic efficiency of a CLC-laser conducted in [4] allowed to explain the reasons for its low power output and ways of its improvement, primarily due to the higher ordering of dye molecules.

(C) I.P. ILCHISHIN, T.V. MYKYTIUK, 2016
The pressing problem in such lasers is the absence of a rapid method of tuning of the lasing frequency. The temperature change of the helix pitch, which was used up to now, appears to be very inertial.

It is known that, in some types of induced CLC based on nematic with chiral dopants (ChD), one can change a molecular conformation of these dopants under UV-irradiation with corresponding changes in their helical twisting power. This type of CLCs, including those with non-mesogenic $\mathrm{ChD}$, can provide a variation of their helical pitch under the excitation of certain molecular stereoisomeric forms because of the presence of different photoisomer forms of molecules and the easiness of their phototransformation.

A variation of the helical pitch under the influence of light is due to a change in the helical twisting power of chiral molecular switches in CLC as a result of the photoconversion of molecules of a chiral dopant [5-8] or liquid crystal host [9-12]. These phototransformation (e.g., photo-Fries reaction, photol-

\footnotetext{
1 This work was reported at the XXII International SchoolSeminar of Galyna Puchkovska "Spectroscopy of Molecules and Crystals" (20-27 September 2015).
}

ISSN 2071-0194. Ukr. J. Phys. 2016. Vol. 61, No. 9 
ysis reaction, etc.) cause often irreversible changes in the helical pitch $[6,8]$. However, some phototransformations (such as a trans-cis isomerization of azo and azoxy-compounds) are generally reversible; the photo-excited cis isomers of such molecules relax to the initial trans form, when heated or exposed to light of various wavelengths. The case of cis-trans photoisomerization is the most interesting, because it allows one to change the frequency of lasing in two opposite directions by means of the same quite technological factor, namely, light.

Previously, the ability to change a twisting of CLC by varying the concentration of isomers was used to change the frequency of a CLC-laser, but the reversal was not obtained $[6,8]$. Recently, the reversing of the helical pitch of CLC was obtained on a material with azoxy-groups [9-11].

In this work, we will study the frequency phototuning of a CLC-laser, by using materials that provide both its reversal and a rapid tuning of the frequency with the use of a highly photosensitive azo-dopant.

\section{Experimental Part}

As the matrix in a realization of the reversible phototuning, we used CLC mixtures composed of $36 \%$ Tekon-20 (analog of cholesteryl oleate) $+64 \%$ mixtures of nematic liquid crystals ZhK-654, which incorporates $66 \%$ ZhK-440, whose molecules have azoxygroups. CLCs were activated by phenolenone dye F490 at a weight concentration of $0.3-0.4 \%$. The cell thickness with this CLC was $40 \mu \mathrm{m}$.

To fabricate CLC for the rapid phototuning, the nematic matrix ZLI-4801 (Merck) was firstly doped with a left-handed ChD S811 (Merck) in an amount of 15 wt. Thus, the selective reflection (SR) band of the induced CLC was placed in the infrared area (>1100 nm). The subsequent addition of $1.3 \mathrm{wt} . \%$ of the left-handed highly sensitive twisting dopant Li-7 to the above mixture shifted the SR band to $550 \mathrm{~nm}$. This CLC was finally activated with pyrrhomethene dye PM 567 from Exciton at a concentration of 0.3 wt.\%. The resulting dye-doped photoresponsive CLC was filled in a LC cell based on ITO/glass substrates coated with rubbed polyimide layers to ensure a uniform planar alignment. The cell thickness was $15 \mu \mathrm{m}$.

The optical pumping of the doped CLC was carried out by the second harmonic at $\lambda=530 \mathrm{~nm}$ of a

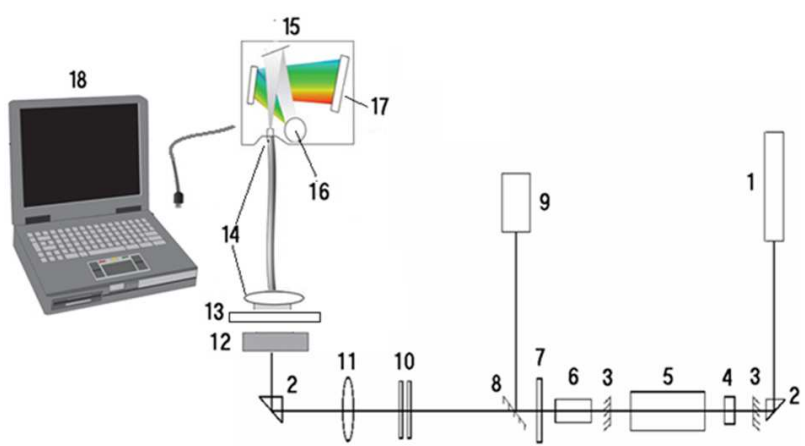

Fig. 1. Scheme of the laser setup: He-Ne laser (1), rotating prism (2), resonator mirrors (3), Q-modulator (4), active element of a solid-state laser (5), frequency doublers $(6)$, filter $(7)$, half mirror (8), calorimeter $(9)$, neutral filters $(10)$, lens (11), dye-doped CLC (12), filter (13), lens with optical fiber (14), spectrometer Ocean Optics USB 2000 (15), diffraction grating (16), CCD matrix (17), computer (18)

Q-switched $\mathrm{Nd}^{3+}$ laser operating in a slow pulse repetition rate mode with the pulse duration $\approx 20 \mathrm{~ns}$. The second harmonic radiation was focused by a lens with a focal distance of $21 \mathrm{~cm}$ on a sample of the dyedoped CLC as a spot $0.5 \mathrm{~mm}$ in diameter. A maximal power density of the second harmonic radiation was $\approx 27 \mathrm{MW} / \mathrm{cm}^{2}$ and attenuated by neutral filters. The lasing spectra of the dye-doped CLC corresponding to each pumping pulse were optically imaged in a focal plane of a spectrograph with an inverse dispersion of $0.6 \mathrm{~nm} / \mathrm{mm}$ and then displayed by the video camera on a PC monitor. The scheme for the rapid phototuning of a lasing frequency is shown in Fig. 1 with the replacement of a spectrograph by a spectrometer Ocean Optics USB 2000.

The UV-vis absorption spectra of the CLC were measured at room temperature by a spectrophotometer SF-20 (LOMO, St.-Petersburg). The fluorescence of the dye in CLC was measured by a spectrometer MPF-4 (Hitachi), and the lasing spectra (with rapid frequency tuning) were recorded with a spectrometer Ocean Optics USB 2000.

For the UV irradiation of samples of the CLC with azoxy-groups in the molecular structure, we used a low-pressure Hg lamp of the DRK-120 type with the air cooling (radiation power $120 \mathrm{~W}$, stabilized discharge current). The change of the CLC helical pitch in the reverse direction is carried out by the same lamp DRK-120 irradiating through a combination of filters ZhS $11+$ interference filter with a maximum 


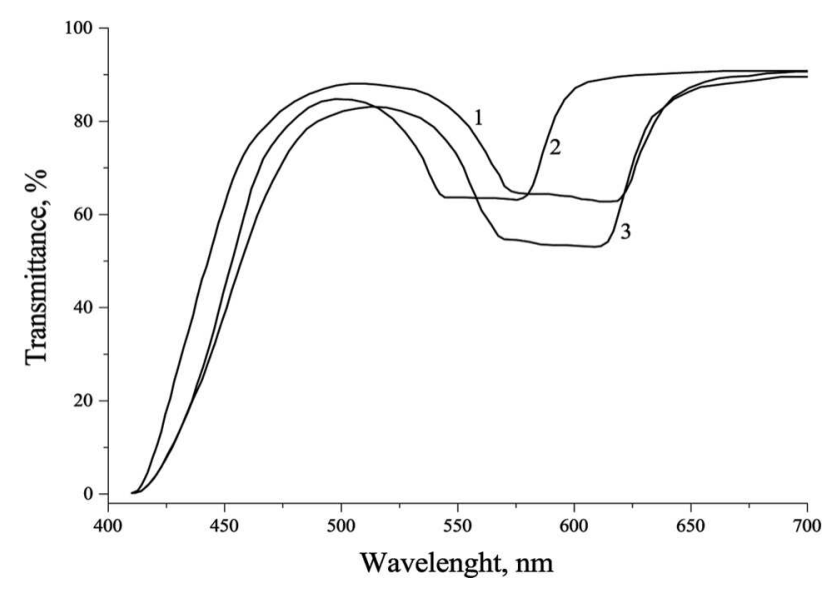

Fig. 2. Transmission spectra of liquid crystal mixtures: $36 \%$ Tekon-20 + 64\% ZhK-654: without UV-exposure (1); 20-min UV radiation (2), 60-min mercury lamp exposure through a combination of filters ZhS-11 + interference filter with 436-nm maximum bandwidth (3). The CLC thickness is $40 \mu \mathrm{m}$

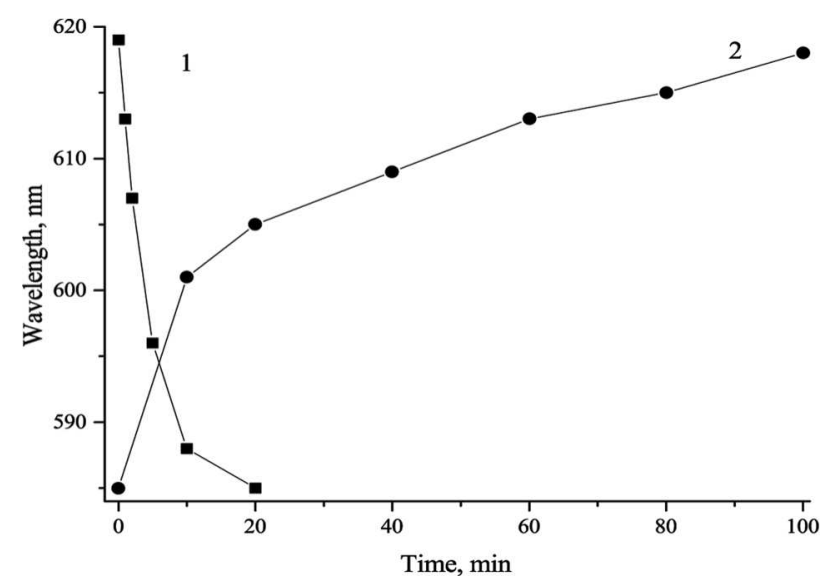

Fig. 3. Tuning the average wavelength in the lasing spectrum of the induced CLC based on $64 \%$ ZhK-654 + 35.7\% Tekon$20+0.3 \%$ doping dye F 490 depending on the duration of UV-irradiation (1) and the reversible phototuning through the filter ZhS-10 under conditions of a constant exposure (2). The CLC thickness is $40 \mu \mathrm{m}$

bandwidth of $436 \mathrm{~nm}$. The irradiation of the CLC with a highly photosensitive azo-dopant was realized by violet and green LEDs with wavelengths of $398 \mathrm{~nm}$ and $519 \mathrm{~nm}$, respectively. The radiation intensities were $12 \mathrm{~mW} / \mathrm{cm}^{2}$ and $10 \mathrm{~mW} / \mathrm{cm}^{2}$ for violet and green diodes, respectively. The diode energies were measured with a meter Melles Griot 13PEM001. The laser diode with a wavelength of $532 \mathrm{~nm}$ and a radiation intensity of $634 \mathrm{~mW} / \mathrm{cm}^{2}$ was used in the

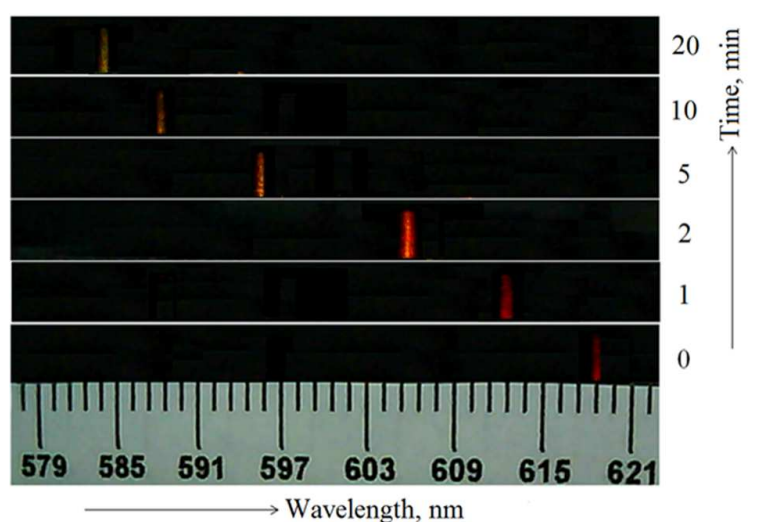

Fig. 4. Phototuning of the lasing spectra for the induced CLC based on a mixture of $36 \%$ Tekon- $20+64 \%$ ZhK- 654 and doping dye F 490 in the forward direction. The CLC thickness is $40 \mu \mathrm{m}$

study of the rapid phototuning associated with the reverse cis-trans isomerization of molecules of highly photosensitive $\mathrm{ChD}$. The exposure time was set by a mechanical shutter and changed by discrete portions with a duration of $8 \mathrm{~ms}$.

When using a CLC based on nematic ZhK-654 having an azoxy-group and the twisting impurity (esters of cholesterol), which has no stereoisomers, we obtained the almost complete reversal of the helix pitch in such a CLC (Fig. 2), unlike the CLC based on nematic ZhK-440, for which an incomplete reversal was obtained [12]. The complete reversal of the helical pitch was obtained for samples with perfect planar texture. To create them, the substrate with a transparent electrode is used.

It was also obtained a complete reversal of the lasing frequency of a CLC-laser (Fig. 3). As can be seen from Figs. 2 and 3, the process of cis-trans isomerization, for which the reversal of a frequency occurs, is much slower. The reason may be the much less absorption at the wavelength allocated to a combination filter ZhS-10 and an interference filter, through which the irradiation of the CLC at the cis-trans photoisomerization is carried out.

Figure 4 shows the tunable lasing spectra of CLC based on a mixture of a nematic ZhK-654 and the twisting dopants Tekon-20. When UV radiation from a lamp DRK-120 comes, the lasing wavelength is changed in the forward direction toward shorter wavelengths. At low excitation levels, only the lowest longitudinal mode is generated. As shown, the laser line has substantially similar lines in the lasing spectra of 
the CLC based on nematic ZhK-440 [12], by virtue a higher threshold lasing in the latter. The phototuning range is $35 \mathrm{~nm}$ in both directions.

For a rapid phototuning of the lasing frequency of a CLC-laser, we used a new more twisting highly photosensitive azo-dopant Li-7 recently synthesized [13]. A feature of this dopant is the fact that the absorption bands of the trans- and cis-forms of these molecules are in the visible region and strongly separated, 408 and $520 \mathrm{~nm}$. Accordingly, the absorption band of the cis-form of a molecule coincides with the frequency of a pump. The latter fact rather restricts its use to produce laser oscillations due to the nonradiative transition from the upper level of doped dye molecules to the appropriate level of a molecule of the twisting dopant.

In order to minimize the excitation energy transfer from the dye molecule to twisting dopant Li-7, we used another twisting dopant S 811 which has no absorption bands of a photoisomer of its molecules in the visible region of the spectrum. The combination of these two twisting dopants S 811 and Li-7 minimizes the process of transfer of the excitation energy from the dye molecules and allowed us to obtain the lasing in a cholesteric liquid crystal with a sufficiently low threshold.

Figure 5 shows the transmission spectra of CLC formed with the use of these two dopants before (1) and after (2) irradiation by a violet LED. Here, the minimum transmittance at $524 \mathrm{~nm}$ is caused by the absorption of the doped dye, and the shoulder on both spectra to the long-wavelength edge of the dye fluorescence spectrum (3) corresponds to a selective reflection of the CLC-matrix. The arrows indicate the position of the lasing spectra with respect to the SRband of the CLC. As can be seen, their location in both cases corresponds to the edge of the SR-band of the CLC.

The lasing in the CLC has been obtained under the pulsed excitation by single pulses of a solid-state laser, the minimum threshold energy was $14 \mu \mathrm{J} /$ pulse at an excitation energy of $36 \mu \mathrm{J} /$ pulse. The irradiation of the dye-doped CLC by purple LED $(\lambda=398 \mathrm{~nm})$ with a power density exposure of $10 \mathrm{~mW} / \mathrm{cm}^{2}$ causes the tuning of the lasing spectrum in the interval from 567 to $593 \mathrm{~nm}$ (Fig. 6, curve 1). The number of longitudinal modes in the spectrum 1 or 2 depends on the level of losses due to the reabsorption of dye molecules at the Stokes shift of $24 \mathrm{~nm}$.

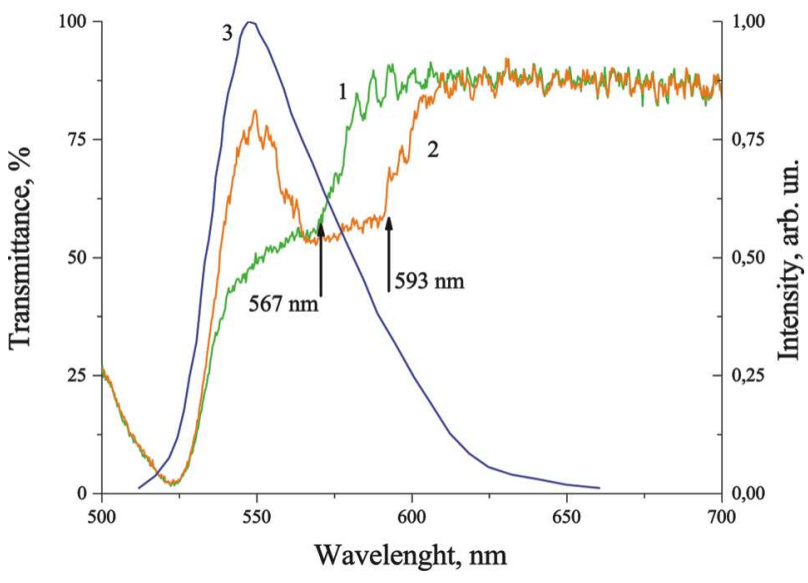

Fig. 5. Transmittance spectra of the dye-doped induced CLC: before irradiation (1); after the exposure by a violet diode for $3 \mathrm{~s}$ (2); fluorescence spectra of PM567 dyes in the CLC (3). The arrow shows the position of lasing. The composition CLC: $83.9 \%$ ZLI-4801 + 14.8\% S811 + 1.3\% Li-7. The CLC thickness is $15 \mu \mathrm{m}$

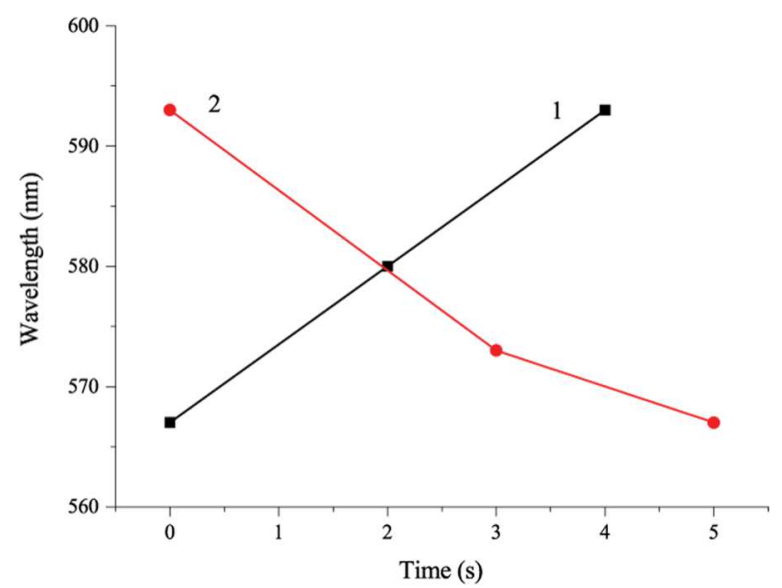

Fig. 6. Kinetics of the direct (curve 1) and reverse (curve 2) phototuning of the lasing wavelength of the induced CLC obtained, respectively, by using violet (curve 1) and green (curve 2) LEDs

To reverse of the lasing frequency, we used the irradiation of the CLC by a green $\operatorname{LED}(\lambda=520 \mathrm{~nm})$ with a power density exposure of $12 \mathrm{~mW} / \mathrm{cm}^{2}$. Figure 6 (curve 2) represents the tuning of the average wavelength in the lasing spectrum of the CLC under such irradiation. As is seen, the tuning frequency is obtained in the same spectral region at close times of irradiation. The spectral composition of the lasing, as in Figure 6 (curve 1), is dependent on the position of the SR-band relative to the maximum of the 


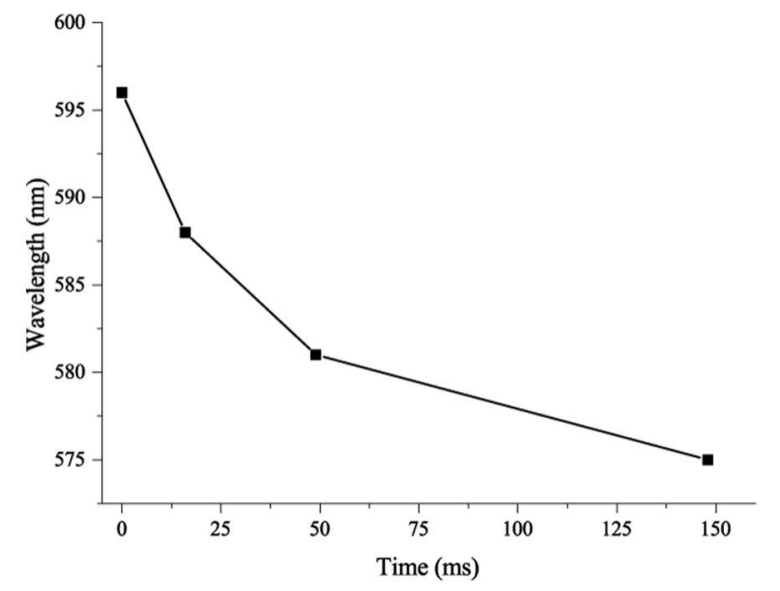

Fig. 7. Kinetics of the reverse phototuning of the lasing wavelength of the induced CLC in the case of irradiation with a green laser diode

spectrum fluorescence of the dye in CLC (Figure 5, curve 3$)$.

To increase the speed of the phototuning of the lasing frequency in such CLC, we used the irradiation from a green laser diode $(\lambda=532 \mathrm{~nm})$ with an intensity of $654 \mathrm{~mW} / \mathrm{cm}^{2}$. The exposure duration from $2 \mathrm{~ms}$ to $300 \mathrm{~ms}$ was controlled by a mechanical shutter. In Fig. 7, we show the reversal of the frequency of the lasing in the CLC under this exposure. The same tuning range as that in Fig. 6 (curve 2) was obtained for $148 \mathrm{~ms}$, which is three orders of magnitude less than the time of a phototuning with the use of the previously used azo- and azoxy-liquid crystalline materials. It should be noted that a more non-linear curve of the phototuning and a further increase in the phototuning speed can be obtained by increasing the concentration of the twisting dopant Li-7 [14].

\section{Conclusions}

The alignment of fields of the phototuning of the lasing frequency in a CLC-laser can be obtained with a sufficient spacing of the absorption bands of trans-cisisomers of the CLC molecules, sufficient absorption in both bands, and high optical quality of the planar texture. The sharp increase in the speed of the phototuning of the lasing frequency in a CLC-laser can be obtained with the use of the trans-cis isomerization in a highly photosensitive twisting azo-dopant absorbing at the pump frequency of a laser. To minimize the energy transfer from the dye molecules to the molecules of the additive dopant and, thereby, to increase the pump threshold require the use of the second dopant additives and dye with a high quantum yield of fluorescence. We have achieved the time of phototuning of the lasing frequency in the CLC reduced by three orders of magnitude and have developed a method of rapid phototuning, which has no analogs in the world.

1. I.P. Ilchishin, E.A. Tikhonov, V.G. Tishchenko, and M.T. Shpak, Tuning of the emission frequency of a dye laser with a Bragg mirror in the form of a cholesteric liquid crystal, Sov. J. Quantum. Electron. 8, 1487 (1978).

2. I.P. Ilchishin, E.A. Tikhonov, V.G. Tishchenko, and M.T. Shpak, Generation of a tunable radiation by impurity cholesteric liquid crystals, JETP Lett. 32, 24 (1980).

3. I.P. Ilchishin, E.A. Tikhonov, and M.T. Shpak, Peculiarities of the spatial distribution of the lasing of a distributed feedback laser based on cholesteric liquid crystals, Ukr. J. Phys. 33, 10 (1988).

4. I.P. Ilchishin, Optimizing energy output and angular divergence of a DFB laser with cholesteric liquid crystal, Bull. of the Russ. Acad. of Sci. Phys. 60, 494 (1996).

5. V.B. Vinogradov, L.A. Kutulya, Yu.A. Reznikov, V.Yu. Reshetnyak, and A.I. Khizhniak, Photoinduced charge of cholesteric Lc-pitch, Mol. Cryst. Liq. Cryst. 192, 273 (1990) [DOI: 10.1080/00268949008035640].

6. A. Chanishvili, G. Chilaya, G.Petriashvili, R. Barberi, R. Bartolino, G. Cipparrone, A. Mazzulla, and L. Oriol, Phototunable lasing in dye-doped cholesteric liquid crystals, Appl. Phys. Lett. 83, 5353 (2003) [DOI: 10.1063/1.1636818].

7. I. Ilchishin, O. Yaroshchuk, S. Gryshchenko, and E. Shaydiuk, Influence of the light-induced molecular transformations on the helix pitch and lasing spectra of cholesteric liquid crystals, Proc. SPIE 5507, 229 (2004) [DOI: 10.1117/12.569823].

8. S. Kurihara, Y. Hatae, T. Yoshioka, M. Moritsugu, T. Ogata, and T. Nonaka, Photo-tuning of lasing from a dyedoped cholesteric liquid crystals by photoisomerization of a sugar derivative having plural azobenzene groups, Appl. Phys. Lett. 88, 103121 (2006) [DOI: 10.1063/1.2172294].

9. G. Chilaya, A. Chanishvili, G. Petriashvili, R. Barberi, R. Bartolino, G. Cipparrone, A. Mazzulla, and P.V. Shibaev, Reversible tuning of lasing in cholesteric liquid crystals controlled by light-emitting diodes, Adv. Mater. 19, 565 (2007) [DOI: 10.1002/adma.200600353].

10. S.V. Serak, N.V. Tabiryan, G. Chilaya, A. Chanishvili, G. Petriashvili, Chiral azobenzene nematics phototunable with a green laser beam, Mol. Cryst. Liq. Cryst. 488, 42 (2008) [DOI: 10.1080/15421400802240144].

11. H. Kang, M. Choi, Y. Jeong, and J.W. Wu, Effective medium analysis for optical control of laser tuning in a mixture of azo-nematics and cholesteric liquid crystal, J. Opt. Soc. Am. B 27, 204 (2010) [DOI: 10.1364/JOSAB.27.000204].

ISSN 2071-0194. Ukr. J. Phys. 2016. Vol. 61, No. 9 
12. I.P. Ilchishin, L. N. Lisetski, and T.V. Mykytiuk, Reversible phototuning of lasing frequency in dye doped cholesteric liquid crystal and ways to improve it, Opt. Mat. Express 1, 1484 (2011) [DOI: 10.1364/OME.1.001484].

13. T.-H. Lin, Y. Li, C.-T. Wang, H.-C. Jau, C.-W Chen C.-C. Li, H.K. Bisoyi, T.J. Bunning, and Q. Li, Red, green and blue reflections enabled in an optically tunable selforganized 3D cubic nanostructured thin film, Adv. Mater. 25, 5050 (2013) [DOI: 10.1002/adma.201300798].

14. T.V. Mykytiuk, I.P. Ilchishin, O.V. Yaroshchuk, R.M. Kravchuk, Y. Li, and Q. Li, Rapid reversible phototuning of lasing frequency in dye-doped cholesteric liquid crystal, Opt. Lett. 39, 6490 (2014) [DOI: 10.1364/OL.39.006490].

І.П. Ілъчишин, Т.В. Микитюк Received 28.10.15

\section{ФОТОПЕРЕСТРОЮВАННЯ ЧАСТОТИ}

ХРК-ЛАЗЕРА І ШЛЯХИ ЙОГО ОПТИМІЗАЦІЇ

Р е 3 ю м е

Представлено результати наших досліджень по фотоперестроюванню частоти лазерної генерації в індукованих холестеричних рідких кристалах (XPK) шляхом зміни концен- трації фотоізомерів молекул ХРК з азо- і азокси-групами, як у закручуючих нематик домішках, так і в самих нематиках при селективному опроміненні. При використанні нематиків з азокси-групами типу ЖK-654, у яких закручуючими домішками були ефіри холестерину (без фотоізомерів), досліджено умови мінімізації порога генерації в XPKлазері на їх основі і розширення діапазону фотоперестроювання частоти. Вивчено вплив якості орієнтації рідкого кристала на пороги лазерної генерації і діапазон фотоперестроювання частоти. Отриманий час фотоперестроювання частоти генерації в таких XРК-лазерах становить десятки хвилин і зумовлений близькістю смуг поглинання обох стереоізомерів та малою їх величиною. Отримано зменшення часу фотоперестроювання при використанні високочутливої закручуючої домішки, яка поглинає світло на частоті збуджуючого лазера. Вперше отримано лазерну генерацію на такому індукованому XРК. Рекордний час перестроювання довжини хвилі лазерної генерації (21 нм за 148 мс) було отримано при опроміненні лазерним діодом з довжиною хвилі 532 нм. Таким чином, отримано зменшення часу фотоперестроювання майже на 3 порядки порівняно з відомими ХРК-матеріалами. 